Discussion Paper No. 929

\title{
DECOMPOSING THE EFFECT OF HEIGHT ON INCOME IN CHINA: THE ROLE OF MARKET AND POLITICAL CHANNELS
}

\author{
Eiji Yamamura \\ Russell Smyth \\ Yan Zhang
}

March 2015

The Institute of Social and Economic Research

Osaka University

6-1 Mihogaoka, Ibaraki, Osaka 567-0047, Japan 


\title{
Decomposing the effect of height on income in
}

\section{China: The role of market and political channels}

\author{
Eiji Yamamura* \\ Seinan Gakuin University, Japan \\ Russell Smyth \\ Monash University, Australia \\ Yan Zhang \\ Fukuoka Women's University, Japan
}

${ }^{*}$ Corresponding author. Department of Economics, Seinan Gakuin University, 6-2-92 Nishijin, Sawara-ku Fukuoka 814-8511, Japan.

E-mail address: yamaei@seinan-gu.ac.jp

Tel: +81 92823 4543; Fax: +81928232506 


\begin{abstract}
It is well known that height is positively associated with earnings. Based on individual level data, this paper investigates the channels through which height influences income in China. Our first key finding is that taller people are more likely to become members of the Communist Party, resulting in an increase in their income level. We label this the height premium in earnings through the political channel. Second, controlling for the political channel of the height premium, height is positively associated with income in the labor market. We label this the height premium through the market channel. Third, the height premium in earnings through the market channel is larger than that through the political channel.
\end{abstract}

JEL classification: J08; J24; P26

Keywords: Labor market, China, Height, Communist membership. 


\section{Introduction}

It is widely acknowledged that human capital, accumulated through education and experience, is positively correlated with income in a market economy. In addition, an increasing number of studies suggest that individuals' physical characteristics are related to economic returns ${ }^{1}$. One key physical characteristic is height, which has attracted much attention among researchers ${ }^{2}$. Existing studies have explored the role played by height in the labor market and found a height-wage premium in developed Western countries (Schultz 2002; Heineck 2005, 2009; Case \& Paxson 2008, 2009; Kortt \& Leigh 2010). The height-wage premium has also been observed in China (Gao \& Smyth 2010) ${ }^{3}$. Height reflects the degree of investment in health human capital, which improves performance in the labor market.

The contribution of individual ability and skill to the wage premium can be expected to vary under different institutional conditions and, in particular, between market and non-market economies. Our contribution is to analyze the height-wage premium in China by paying particular attention to the institutional setting. Specifically, we consider the role of alternative channels, which we label market and political channels, in contributing to the height-wage premium. In China, the rapid development of the market has been an outgrowth of economic reform. Hence, one reason why health human capital, reflected in height, has been important in increasing earnings might be that human capital plays an important role in the market economy ( $\mathrm{Li}$ 2003). We call this the market channel. However, in China, not only human capital but also political capital should be taken into account when considering the factors that contribute to economic success (Bian et al. 2001; Liu, 2003; Li et al. 2007). Communist Party members have been found to earn higher wages in China (e.g. Appleton et al. 2005; Bishop \& Liu 2008). We define the political channel as the potential height-wage premium that accrues if taller people are more likely to become members of the Chinese Communist Party.

A natural question to ask is how is height is evaluated in terms of politics? If height is positively regarded not only in the "labor market" but also in the "political market", the height premium in earnings may be generated indirectly through the

\footnotetext{
1 Previous studies provide evidence of the beauty premium in the labor market (e.g. Hamermesh and Biddle 1994; Biddle \& Hamermesh 1998; Borland \& Leigh, 2014; Hamermesh et al., 2002).

${ }^{2}$ Weight is also observed to affect wage levels (Brunello \& D'hombres, 2007; Shimokawa 2008).

3 Other studies have examined the relationship between height and living standards in China (Morgan 2000; 2004) and the role of height in dating in China (Ong, 2014).
} 
political channel. We attempt to assess whether height is related to earnings through the political channel and the relative role of the market and political channels. We find that height is positively related to income, not only through the market channel but also through political channel. The association via the market channel, though, is overwhelmingly larger than that through the political channel.

The rest of this paper is organized as follows. In Section 2, the Chinese context and existing literature is reviewed. Section 3 proposes several testable hypotheses. Section 4 provides an overview of the data and empirical method. Section 5 presents, and discusses, the major findings. The last section concludes.

\section{Chinese context and existing literature}

The Chinese Communist Party maintained a high level of control over the wage and promotion structure prior to the market reform period (Groves et al., 1995). In the planning period, members of the Communist Party benefited from better entry-level jobs and career paths (Walder, 1995). In the market reform period, beginning in the 1980s in urban areas, the Communist Party relaxed its formal control over the allocation of labor and wage setting is now more flexible. Enterprises, even in the state sector, now have much more managerial autonomy and wages and promotion are more closely linked to performance and productivity. Moreover, the operation of market forces has been entrenched through a withering of the state-owned sector and a rapid expansion of the private sector. The private sector, broadly defined to include firms with foreign capital, accounted for just under three quarters of industrial output in 2011. At the same time, the state-owned share of industrial output was 26\% in 2011, compared with almost 80\% in 1979 (Lardy, 2014).

The screening criteria for Party membership have changed over time (Han, 2007). Prior to the market reform period, the primary criteria for Party membership was loyalty to the Party and class origin. In the market reform period, and particularly since the 1990s, ability has become the most important criteria with much more emphasis placed on education (Appleton et al. 2009). In 1990 less than $1 \%$ of Party members were college students. By 2005, this figure had increased to $8 \%$ with one quarter of all new members being college students (Han, 2007). At the same time, the importance of class origin, as a screening criteria, has declined over time. Walder (1995) and $\mathrm{Li}$ and Walder (2001) argue that the Party seeks out individuals with high ability and rewards them through the market mechanism as part of a strategy to enable it to maintain its stranglehold on political power. 
Our study is related to at least four strands of literature on the Chinese economic and political landscape. The first is studies examining the determinants of who becomes a Party member (Bishop \& Liu, 2008; Han, 2007). The second is studies examining the economic returns to being a Party member (see eg. Appleton et al., 2009; Bishop \& Liu, 2008; Lam, 2003; Li et al., 2007; Liu, 2003). The third is studies examining the changing role of Party membership in obtaining elite occupations and other benefits ( $\mathrm{Li} \&$ Walder, 2001; Walder, 1995). The fourth is studies examining the economic returns to physical appearance in the Chinese labor market, including height (Gao \& Smyth, 2010) and weight (Shimokawa, 2008). There are no studies examining the relative importance of the market and political channels influencing the height-wage premium. We consider the role of height as a screening criteria for Party membership, in effect proxying for unobservable ability, and the direct and indirect economic returns to height in the labor market.

\section{Hypotheses}

The Party uses height as a screening device to attract talented individuals. Bishop and Liu (2008) found that the Party acts as a screening device to identify less well educated, but high ability, individuals. The problem is that innate ability is unobservable. Height captures unobserved characteristics such as innate ability. Several studies conclude that height is a good proxy for cognitive ability and that the association between height and cognitive ability persists through life (see eg. Case \& Paxson, 2008). Clearly height is a marker for political success. Persico et al. (2004) reported that Presidents of the United States are inclined to be taller than the average American population and that taller candidates tend to win Presidential elections. It is reasonable to think that taller people use Party membership to derive economic rents. Height is a proxy for ability and it is in the interests of the Party to reward Party members of high ability for their loyalty through the market (Walder, 1995). In China, the increasing acceptance of income inequality may make it easier for Party members to convert their political power into economic power, allowing them to earn higher income (Bishop \& Liu 2008). Party members of high ability, proxied by height, are best placed to convert political power into economic power in the market. This suggests the following hypothesis:

Hypothesis 1: Height and income are positively correlated via the political channel

We now turn to why height is rewarded in the market independent of any 
possible political channel. First, taller people tend to be stronger and, hence, can be expected to be more productive, particularly in jobs involving physical labor (Lundborg et al., 2014). This can be especially important in many sectors in developing countries, such as China. Second, as discussed above, height is associated with cognitive ability, which can be expected to be rewarded in the market (Case \& Paxson, 2008). Third, height in adulthood depends on height in adolescence. Persico et al. (2004) argues that individuals who are taller during adolescence are better able to accumulate human capital in adolescence and this is rewarded in later life in the labor market. Fourth, taller people may have higher self-esteem or exude more self-confidence. This may allow them to communicate with colleagues better and, hence, make them more productive. Similarly, taller people may be better negotiators and thus better able to negotiate higher salaries with employers in the labor market. These arguments suggest the hypothesis:

Hypothesis 2: Height and income are positively correlated via the market channel

Next, we consider the relative strength of the relationship between height and income for males and females. We conjecture that the relative strength of the relationship between height and income will be more important for males than females. First, as discussed above, height is likely to be correlated with productivity in jobs involving physical labor. Males will tend to be disproportionately represented in physically demanding jobs, suggesting the height-wage premium will be larger for males. Second, height is correlated with dominant personality traits that are rewarded in the market. Evolutionary psychology suggests that these are more important for males than females (Blaker et al., 2013).

Hypothesis 3. The positive correlation between height and income via both market and political channels will be stronger for males than females.

There has been an expansion of market forces over the reform period. The economic reforms have created a 'space' in which markets have flourished and wages are flexible. One would expect that in such an environment human capital and physical characteristics would have a significant influence on economic returns. The evidence suggests it does. Returns to human capital have increased over the market reform period (Gao \& Smyth, 2015). Studies have identified that physical appearance captured by beauty (Hamermesh et al., 2002), height (Gao \& Smyth, 2010) 
and weight (Shimokawa, 2008) earn economic rents/penalties. While the market has increased in importance in the allocation of resources, the wage premium from being a Party member has not declined. On the contrary, the evidence from existing studies is that it has increased (Appleton et al., 2009; Bishop \& Liu, 2008).

The effect of the market channel on height, however, is direct, while the effect of the political channel on height is indirect via political influence. Therefore, while we expect both political and market channels to positively influence the height-wage premium, the direct effect of the market channel can be expected to have increased relative to the indirect effect of the political channel. This reflects the fact that the Party has reduced its formal role in the allocation of resources (at the expenses of the market) and that while this is extensive, its influence is more subtle. Thus, we expect the market channel to be larger, suggesting the hypothesis:

Hypothesis 4. The effect of height on income via the market channel will be larger than the effect of height on income via the political channel.

\section{Data and methods}

\subsection{Data}

We use data from the Chinese General Social Survey 2008 (CGSS 2008) collected by the Department of Sociology, Renmin University of China, Beijing in 20084. CGSS 2008 was a nationally representative survey, administered in 27 provinces, collected between September and December 2008. All respondents are Chinese with an urban hukou (household registration) and are aged 18 and above. The data were collected via face-to-face interview, in which the questionnaires were filled in by the interviewers. The initial sample size was 6000 , but the number of observations used in this study was reduced to 3581 once missing observations were removed 5 .

The GGSS 2008 contains information regarding basic socioeconomic individual characteristics such as age, gender, household income, occupation, ownership form of employer, years of schooling, marital status, family members and province of residence. Importantly, in terms of our research question, the dataset also contains information on the respondent's height, whether the respondent is a member of the Communist Party,

\footnotetext{
4 The CGSS 2008 has been conducted as a part of the East Asian Social Survey 2008 (EASS 2008) project. EASS 2008 was designed to contribute to the broader provision of Cross-National Survey Data Sets concerning "Culture and Globalization in East Asia". Other datasets in the same series are the Japanese General Social Survey (JGSS), Korean General Social Survey (KGSS) and Taiwan Social Change Survey (TSCS).

${ }^{5}$ See Bian and $\mathrm{Li}$ (2012) for details on sample design, data collection and quality control in the CGSS.
} 
and if his (her) father and mother is a member of the Communist Party. The great advantage of the dataset is that it allows us to assess not only effect of respondent's height and Communist membership, but also that of parent's Party membership.

Table 1 shows the definitions of variables used in this paper and their basic statistics, such as mean value, standard deviation, maximum and minimum values. Apart from these variables, as discussed below, various control variables are included in the empirical specification, but the results for these variables are not reported to conserve space. Hence, information about control variables is omitted in Table 1

- We see from Table 1 that the mean value for Male is 0.48 , indicating that the sample almost equally consists of males and females. Mean values of Party, Father Party and Mother Party are 0.11, 0.13, and 0.02, respectively. This suggests that $11 \%$ of respondents are Communist Party members, $13 \%$ of respondents' fathers are Communist Party members and that $2 \%$ of respondents' mothers are Party members. Therefore, the number of male Party members in the sample is approximately five times larger than that of the number of female members. Accordingly, compared with females, males can be considered to have a political advantage in terms of pursuing institutional rents by virtue of being members of the Communist Party.

Table 2 shows the difference in income between Communist Party members and non-members. Based on the full sample, income of members is higher by $9800 \mathrm{RMB}$ than that of non-members and this difference is statistically significant at the $1 \%$ level. If the sample is restricted to males, the difference in income is $7900 \mathrm{RMB}$, while for the female sample the difference in income is $9500 \mathrm{RMB}$. Hence, the difference in income between Communist members and non-members is larger for females than for males. This implies that Communist Party membership plays a greater role in increasing income for females than for males (assuming all other things equal). Table 2 also shows the difference in income between male and female Communist Party members and the corresponding difference for non-members. It is interesting to observe that there is no statistical difference in income between male and female Communist members, while for non-members the income of males is $5900 \mathrm{RMB}$ higher than for females, which is statistically significant at the $1 \%$ level. All in all, the difference in income between males and females is smaller than the difference in income between members and non-members. That is, in China, Communist Party membership plays a more important role in contributing to differences in income levels than gender differences.

Figures 1 (a) and (b) illustrate the relationship between height and income for males and females. A positive relationship is observed in Figures 1(a) and (b), 
indicating a height premium in earnings for males as well as females. This is in line with previous findings for China reported in Gao and Smyth (2010).

Table 3 shows differences in height between Communist Party members and non-members. We see from Table 3 that, based on the full sample, the height of Communist Party members is higher by 4.2 centimeters $(\mathrm{cm})$ than that of non-members and the difference is statistically significant at the $1 \%$ level. Even after dividing the sample into males and females, the height of members is higher than non-members for males and females. The differences are $1.2 \mathrm{~cm}$ and $1.7 \mathrm{~cm}$ for males and females, respectively. Figures 2 (a) and (b) illustrate the relationship between height and Party membership for males and females. We observe a positive relationship in Figures 2 (a) and (b), implying that the taller people are, the more they are likely to be a member. It follows from Table 3 and Figures 2(a) and (b) that there is a height premium for being a Communist Party member.

\subsection{Methods}

In order to assess the channels through which height has an effect on income, we adopt the following approach. In the first step, a probit model is used to ascertain the determinants of being a Communist Party member. We examine the relation between height and membership. The estimated function takes the form as below:

$$
\begin{gathered}
\text { Party }_{i}=\alpha_{0}+\alpha_{1} \text { Height }_{i}+\alpha_{2} \text { Father Party }_{i}+\alpha_{3} \text { Mother Party }_{i}+\alpha_{4} \text { Schooling }_{i}+ \\
\alpha_{5} \text { Age }_{i}+\alpha_{6} \text { Age squared }_{i}+\alpha_{7} \text { Male }_{i}+\mathrm{Y}_{i}{ }_{i}+u_{i}
\end{gathered}
$$

where Party $i$ represents the dependent variable for individual $i$. The main independent variables are shown in the function. From our argument thus far, the coefficient of Height is expected to have a positive sign. Appleton et al. (2009) argued: "The Party looks for recruits who are committed to its values and will participate actively in politics" (Appleton et al. 2008, 260). If one's parents are members of the Party, this is a key leading indicator. Thus, parental membership of the Communist Party is an indicator of loyalty and sound class background (Appleton et al. 2008). The coefficients on Father Party and Mother Party are expected to have a positive sign. If this proves to be correct, political advantage can be considered to be inherited from generation to generation. Schooling is included to determine the extent to which human capital, through education, plays a role in "the political market". The predicted sign of Schooling is positive. Further, basic demographic factors are taken into account by including age and gender. Apart from 
these variables, the vectors of the control variables are denoted by $\mathrm{Y}_{i}$. These control variables are residential province dummies, health status dummies, dummies for location of the school from which respondents graduated, dummies for number of family members, occupation dummies, dummies for ownership form of employer and marital status dummies. The regression parameters are denoted by $\alpha$, and $B$ is the vector of the regression parameters for the control variables. The error term is denoted by $u$. The empirical specification follows the model employed by Appleton et al. (2009) to examine the determinants of Communist Party membership.

In the second step, we investigate the determinants of annual income level ${ }^{6}$. Income of some respondents is zero, representing left-censored observations. In these circumstances the Tobit model is suitable and is so used for estimation ${ }^{7}$. The estimated function takes a similar form to that used in the first step estimation:

$$
\begin{gathered}
\text { Income }_{i}=b_{0}+b_{1} \text { Party }_{i}+b_{2} \text { Height }_{i}+b_{3} \text { Father Party }{ }_{i}+b_{4} \text { Mother Party }{ }_{i} \\
+b_{5} \text { Schooling }_{i}+b_{6} \text { Age }_{i}+b_{7} \text { Age squared }_{i}+b_{8} \text { Male }_{1}+\mathrm{Z}_{i}{ }_{i} C_{i}+e_{i}
\end{gathered}
$$

In addition to the set of independent variables used in the first step estimation (probit model), Party is included to examine the association between income and party membership, which captures political influence on income. Considering the results for Height in the probt and Tobit estimation allows us to assess the height premium on income through the political channel. Since, in the Tobit estimation, the effect of height on income via the political channel is controlled by including Party, the result for Height in the Tobit model captures the effect of height via the market channel. As for other control variables, most of them are widely used in the

\footnotetext{
${ }^{6}$ Using hourly wages is preferable to income (Li, 2003). However, hourly wage cannot be obtained from CGSS 2008 and so annual income level is used. Annual income has been employed as the dependent variable in related studies, such as Bishop and Liu (2008). 7 In the existing literature, the logarithm of hourly wage (or income) is used as the dependent variable. However, respondents reporting no income would need to be deleted from the sample if we used that approach in this paper. This leads to selection bias. Therefore, we do not use logarithm of income in this paper. Instead of using logarithm of income, the semi-elasticity $(\mathrm{d}(\ln \mathrm{y}) / \mathrm{d}(\mathrm{x}))$, is numerically calculated after estimation. 8 There is an argument that the Communist Party seeks to recruit economically productive members (Appleton et al. 2009). Hence, people with higher earnings are possibly likely to be Communist Party members. If this holds true, causality between income and Party membership is ambiguous, resulting in problems of endogeneity bias. There is an argument that "parental membership is likely to be correlated with own membership... [but] parental membership may not have a strong direct effect on own wages" (Appleton et al. 2009, 266). Following this argument, we used parental membership dummies (Father member and Mother member) as exogenous instruments for Party to conduct 2SLS estimation. However, results of the endogeneity test for Party did not suggest that Party is an endogenous variable in any estimations (as is reported in Tables 4-6). Therefore, Party is treated as an exogenous variable in the Tobit estimation. This is the reason why the probit estimation and Tobit estimation are conducted separately.
} 
existing literature when considering determinants of wage or income (e.g. Appleton et al., 2005, 2009; Bishop and Liu 2008; Gao and Smyth 2010, 2015).

We use the full sample in order to test Hypotheses 1 and 2 proposed in Section 3. We divide the sample into males and females to test Hypotheses 3 and 4

\section{Results and discussion}

The regression estimates for both the probit and Tobit specifications are reported in Tables 4-6. Results based on the full sample are presented in Table 4. After dividing the sample into males and females, results based on the male sample are presented in Table 5, while those based on the female sample are presented in Table 6 . In each Table, results for the probit model are shown in column (1), while those for the Tobit model are in column (2). In the probit estimation, values without parentheses show the marginal effect, indicating the change in probability of being a Communist Party member when the independent variable increases by one point. In the Tobit estimation, values without parentheses ${ }^{9}$ show the change in the logarithm of income when the independent variable increases by one point.

First, we begin by interpreting the results in Table 4. Consistent with expectations, the coefficient on Height has a positive sign and is statistically significant at the $1 \%$ level in column (1). This suggests that height plays a critical role in selecting individuals to be Communist Party members. The absolute value of its coefficient is 0.003 , indicating that a $1 \mathrm{~cm}$ increase in height leads to $0.3 \%$ increase in probability that one becomes a member. Coefficients on Father party, and Mother party also have a positive sign and are statistically significant at the $1 \%$ level in column (1). This means that parental membership increases the likelihood that individuals become Party members, which is consistent with class background being used as a screening criteria. Absolute values of the coefficient on Father party and Mother party are 0.058 and 0.092, suggesting that the probability that individuals become a Party member is higher by $5.8 \%(9.2 \%)$ if their father (mother) is a member. In addition, in line with expectation, Schooling yields a significantly positive sign, such that higher education leads individuals to become members. The coefficient on Male is also positive and statistically significant. This result suggests that the gender difference in the probability of becoming a Communist Party member is persistently observed in 2008, although Appleton et al. (2009) reported that the difference diminished from 1988 to 1999.

\footnotetext{
9 The value is the semi-elasticity $(\mathrm{d}(\ln y) / \mathrm{d}(\mathrm{x}))$, which is calculated at the means of the independent variables after estimation.
} 
We now turn to the results in column (2) in Table 4. The coefficient on Party has the expected positive sign and is statistically significant at the $1 \%$ level. This means that Communist Party membership is positively associated with income. The absolute value of the coefficient is 0.222 , which implies that Communist Party members' income is $22.2 \%$ larger than non-members. On the other hand, the coefficients on Father party, and Mother party are not statistically significant. Therefore, parental membership is not associated with income through the market channel. The combined results of Party, Father party, and Mother party imply that the market functions well and that parent's political power is associated with income only through the political channel and not through the market channel ${ }^{10}$. In the case of parental membership, such reverse causality does not hold. Consistent with the prediction, the sign on the coefficient of Height is positive and statistically significant at the $1 \%$ level. Therefore, even after controlling for the effect of height on income via the political channel, height is positively related to income. The significant positive sign for Schooling is in line with standard economic theory. The sign on Male is positive and significant, suggesting that females are discriminated against in the labor market. The results for Schooling and Male are consistent with extant studies (Appleton et al. 2005, 2009; Gao \& Smyth, 2015). Combined results in columns (1) and (2) of Table 4 strongly support Hypotheses 1 and 2.

Let us switch attention to Tables 5 and 6 . Here, we focus on a few key variables; Party, Height, Father party and Mother party. In column (2) of Table 5, Party, Height, Father party and Mother party all have a statistically significant positive coefficient. This is in line with expectations. With respect to column (2) of Table 5, a significant positive sign is observed for the coefficient on Party and Height. Father party and Mother party have a negative sign, but are not statistically significant. In columns (1) and (2) of Table 6, the results are similar to Table 5. The absolute value of the coefficient of Father Party is larger (smaller) than that of Mother Party in Table 5 (Table 6). This can be interpreted as implying that if the respondent's parent is a Party member of the same gender as the respondent this has a larger influence on the probability that the respondent will become a member.

In order to more closely examine the effect of parental membership and height on income, we now turn to Tables 7 and 8 . Table 7 suggests the effect of parents

10 Bishop and Liu (2008) find that spouse's Communist Party membership is positively associated with income. However, there is the possibility that Communist Party members can marry high earners because of the Party premium in the marriage market. If this holds, reverse causality leads to bias in the results of spouse's membership reported in Bishop and Liu (2008). 
being Party members on income occurs through market and political channels. We see from Table 7 that parental membership is associated with income only through the market channel. One's income level is higher by $2.34 \%(2.22 \%)$ for males (females) whose father (mother) are Party members. On the other hand, income is larger by $1.69 \%(0.51 \%)$ for males (females) whose mother (father) are Party members. This suggests that the membership premium is larger if one has a parent who was a Party member of the same gender. Turning to Table 8 , for males a $1 \mathrm{~cm}$ increase in height leads to a $1.84 \%(0.11 \%)$ increase in income through the market channel (political channel). For females, a $1 \mathrm{~cm}$ increase in height leads to a $0.82 \%$ $(0.08 \%)$ increase in income through the market channel (political channel). This strongly supports Hypothesis 3. Further, the effect of an additional $1 \mathrm{~cm}$ increase in height is larger through the market channel than political channel by an order of magnitude of 20-fold. This result is consistent with Hypothesis 4.

When Tables 7 and 8 are jointly considered, membership of the same sex parents on income through the political channel is larger than the effects of a $1 \mathrm{~cm}$ height effect through the market channel. The father membership effect on male income is equivalent to a $1.22 \mathrm{~cm}$ increase in height through the market channel. The mother membership effect on female income is equivalent to a $2.69 \mathrm{~cm}$ increase in height through the market channel. Therefore, compared with the height effect on income, parent's membership effect through the political channel is two times larger for females than males. Therefore, intergenerational political rent plays a more critical role in terms of income for females than for males.

\section{Conclusion}

A number of studies suggest that height is positively associated with earnings. However, it is likely that the influence of height in the labor market depends on the institutional setting. In a post-socialist economy one expects there to be a political influence on market outcomes For instance, Communist Party membership is thought to influence earnings through the political channel. There is the wage premium associated with being a member of the Party in China (Bishop \& Liu 2008; Appleton et al., 2009). However, little is known about how height is related to Party membership, although a height premium has been observed in the Chinese labor market (Gao \& Smyth 2010). Using individual level data for China, this paper has attempted to decompose the height premium on earnings into a premium through the political channel and a premium through the market channel.

We found that height is positively related to being a member of the Communist 
Party, which in turn leads to an increase in income level. This suggests that height indirectly influences income through the political channel. Even after controlling the height effect through the political channel, height is positively associated with income. Therefore, height affects income not only through the political channel, but also via the market channel. Further, the effect of height through the market channel is much larger (about 20 times larger) than that through the political channel. After dividing the sample into males and females, the height premium from Party membership is larger for males than females. In addition, compared with the height premium on income, parent's membership premium through the political channel is relatively larger for females than males. The take home message is that the market mechanism functions well, although in China specific political power influences the labor market. Political influence on income proves to be more important for females than males. This result could reflect the scarcity of political talent among females compared with males, given there are fewer women in the Party. This, in turn raises the marginal political product of being female. 


\section{References}

Appleton, S., Song, L., Xia, Q. 2005. Has China crossed the river? The evolution of wage structure in urban China during reform and retrenchment. Journal of Comparative Economics 33(4), 644-663.

Appleton, S., Knight, J., Song, L., Xia, Q. 2009. The economics of communist party membership: The curious case of rising numbers and wages premium during China's transition. Journal of Development Studies 45(2), 256-275.

Bian, Y., Li, L. (2012). The Chinese general social survey (2003-2008): sample designs and data evaluation. Chinese Sociological Review 45(1), 70-97.

Bian, Y., Shu, X., Logan, J. 2001. Communist party membership and regime dynamics in China. Social Forces 79, 805-842.

Biddle, J.E., Hamermesh, D.S. 1998. Beauty, productivity and discrimination: Lawyer's looks and lucre. Journal of Labor Economics 16(1), 172-201.

Bishop, J.A., Liu, H. 2008. Liberalization and rent-seeking in China's labor market. Public Choice 135(3-4), 151-164.

Blaker, N., Rompa, I., Dessing, I.H., Vriend, A.F., Herschberg, C., van Bugt, M. 2013. The height leadership advantage in men and women: Testing evolutionary psychology predictions about the perceptions of tall leaders. Group Processes and Intergroup Relations 16(1), 17-27.

Borland, J., Leigh, A. 2014. Unpacking the beauty premium: what channels does it operate through, and has it changed over time? Economic Record 90(288), 17-32.

Brunello, G., D’hombres, B. 2007. Does body weight affect wages? Evidence from Europe. Economics and Human Biology 5(1), 1-19.

Case, A., Paxson, C. 2008. Stature and status: Height, ability and labor market outcomes. Journal of Political Economy 116(3), 499-532.

Case, A., Paxson, C. 2009. Making sense of the labor market height premium: Evidence from the British household panel survey. Economics Letters 102(3), 174-176.

Gao, W., Smyth, R. 2010. Health human capital, height and wages in China. Journal of Development Studies 46(3), 466-484.

Gao, W., Smyth, R. 2014. Education expansion and returns to schooling in urban China, 2001-2010: Evidence from three waves of the China Urban Labor Survey. Forthcoming in Journal of the Asia Pacific Economy. DOI:10.1080/13547860.2014.970607 
Groves, T., Hong, Y., McMillan, J. Naughton, B. 1995. China's evolving managerial labor market. Journal of Political Economy 103(4), 873-892.

Hamermesh, D.S., Biddle, J.E. 2004. Beauty and labor market. American Economic Review 84(5), 174-194.

Hamermesh, D.S., Meng, X., Zhan, J. 2002. Dress for success: Does primping pay? Labour Economics 9, 361-373.

Han, L. 2007. Marketing politics? Economic reforms and the selection of political elites in China. Department of Economics, Harvard University.

Heineck, G. 2005. Up in the skies? The relationship between height and earnings in Germany. Labour 19(3), 469-489.

Heineck, G. 2009. Too tall to be smart. Economics Letters 105(1), 78-80.

Kortt, M and Leigh, A. 2010. Does size matter in Australia? Economic Record 86(272), 71-83.

Lam, K-C. J. 2003. Earnings advantages of Party members in urban China. Business Research Centre Working Paper, Department of Economics, Hong Kong Baptist University.

Lardy, N. R. 2014. Markets over Mao: The rise of private business in China. Washington DC: Peterson Institute for International Economics.

Li, B., Walder, A. 2001. Career advancement as party patronage: Sponsored mobility into the Chinese administrative elite, 1949-1996. American Journal of Sociology 106(5), 1371-1408.

Li, H. 2003. Economic transition and returns to education in China. Economics of Education Review 22(3), 317-328.

Li,H., Liu, P.W., Ma, N., Zhang, J. 2007. Economic returns to Communist Party membership: Evidence from Chinese twins. Economic Journal 117 (527), 1504-1520.

Liu, Z. 2003. The economic impact and determinants of investment in human and political capital in China. Economic Development and Cultural Change 51(4), 823-849.

Lundborg, P., Nystedt, P., Rooth, D.O. 2014. The height premium in earnings: The role of physical capacity and cognitive and non-cognitive skills. Journal of Human Resources 149(1), 141-161.

Morgan, S. 2000. Richer and taller: Stature and standard living in China, 1979-1995. China Journal 44, 1-39.

Morgan, S. 2004. Economic growth and biological standard of living in China, 1880-1930. Economics and Human Biology 2(2), 197-218. 
Ong, D. 2014. Height and income attraction: An online dating field experiment. HSBC Business School, Peking University.

Persico, N., Postlewaite, A., Silverman, D. 2004. The effect of adolescent experience on labor market outcomes: The case of height. Journal of Political Economy 112(5), 1019-1053.

Schultz, T.P. 2002. Wage gains associated with height as a form of health human capital. American Economic Review 92(2), 349-453.

Shimokawa, S. 2008. The labour market impact of body weight in China: A semi-parametric analysis. Applied Economics 40(8), 949-968.

Walder, A. 1995. Career mobility and the Communist political order. American Sociological Review 60(3), 309-328. 


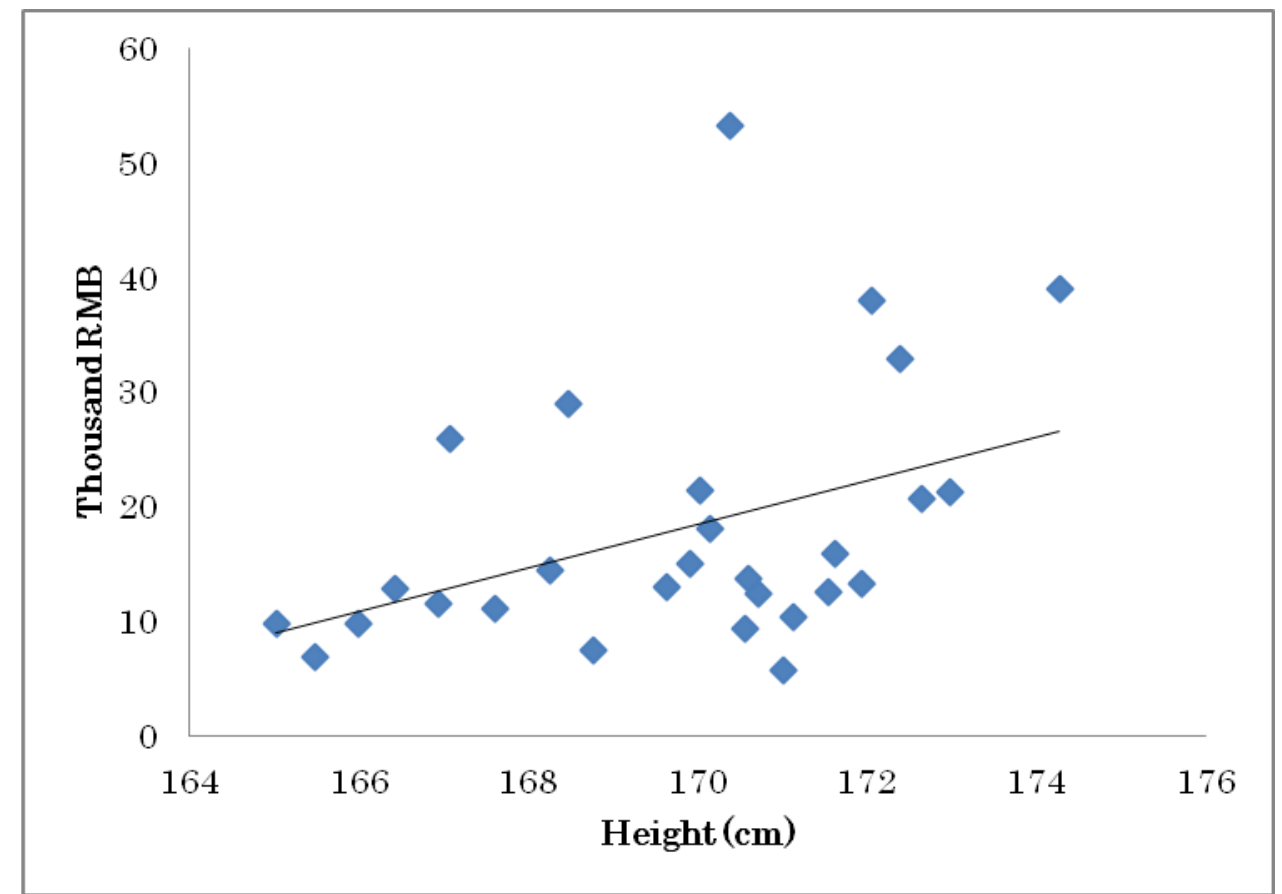

Figure 1 (a). Association between height and income for males.

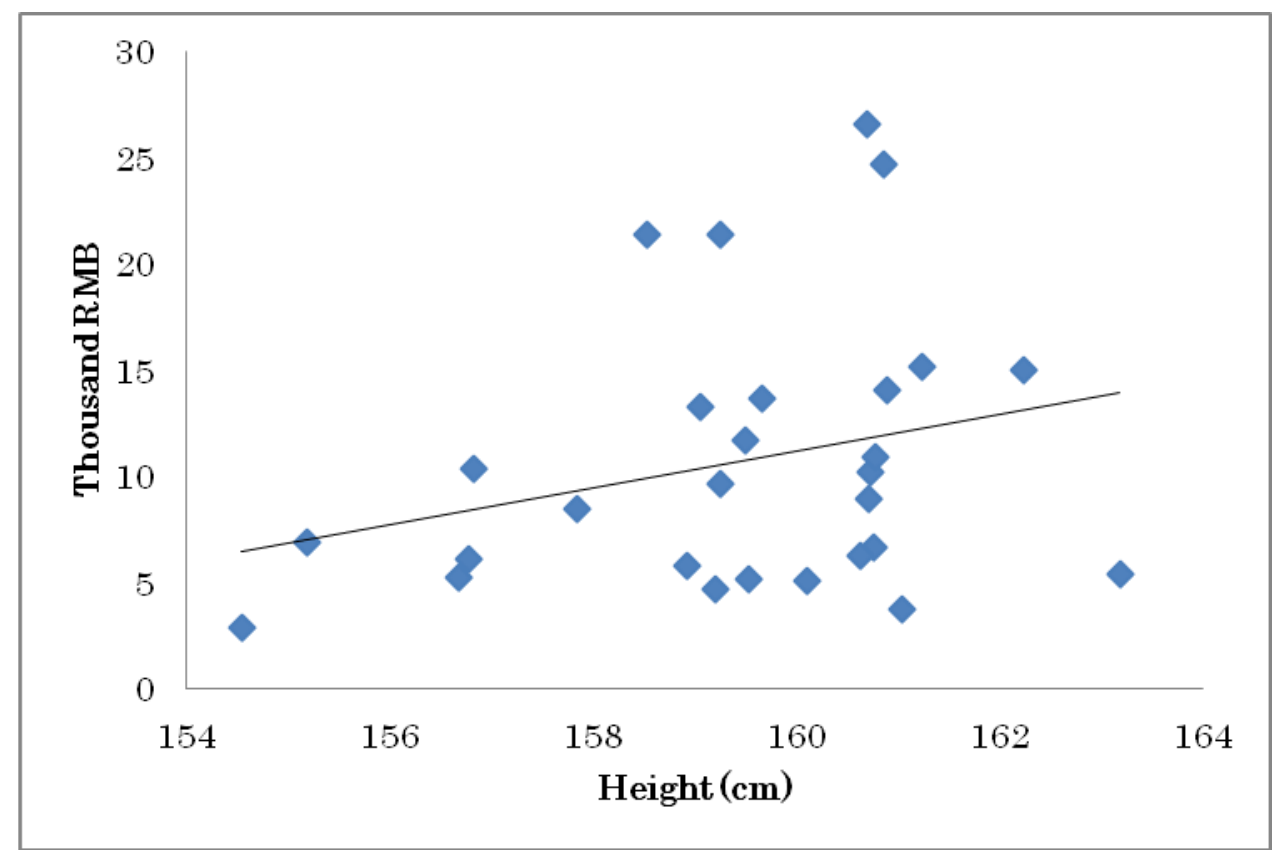

Figure 1(b). Association between height and income for females.

Note: mean value in each province is plotted. 


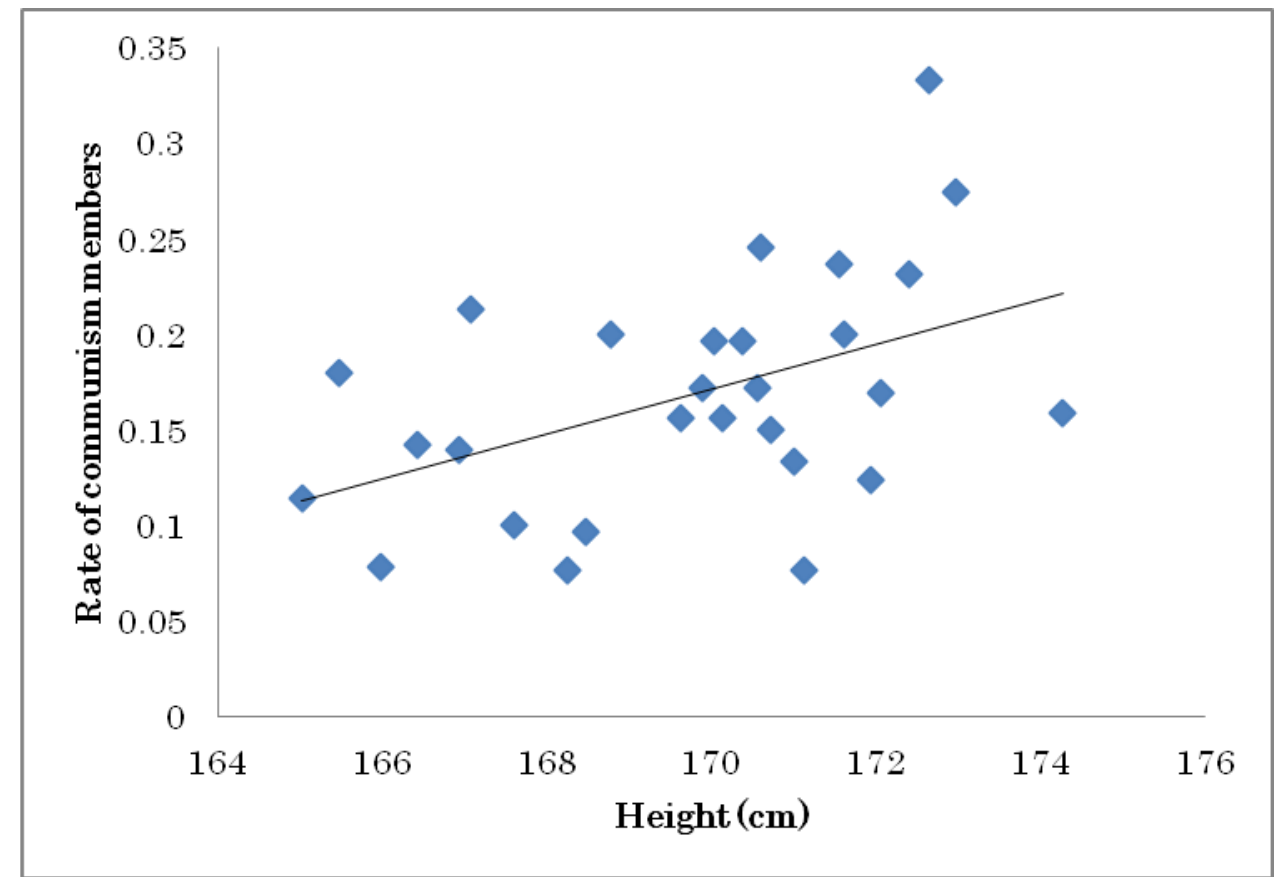

Figure 2 (a). Association between height and Party membership for males.

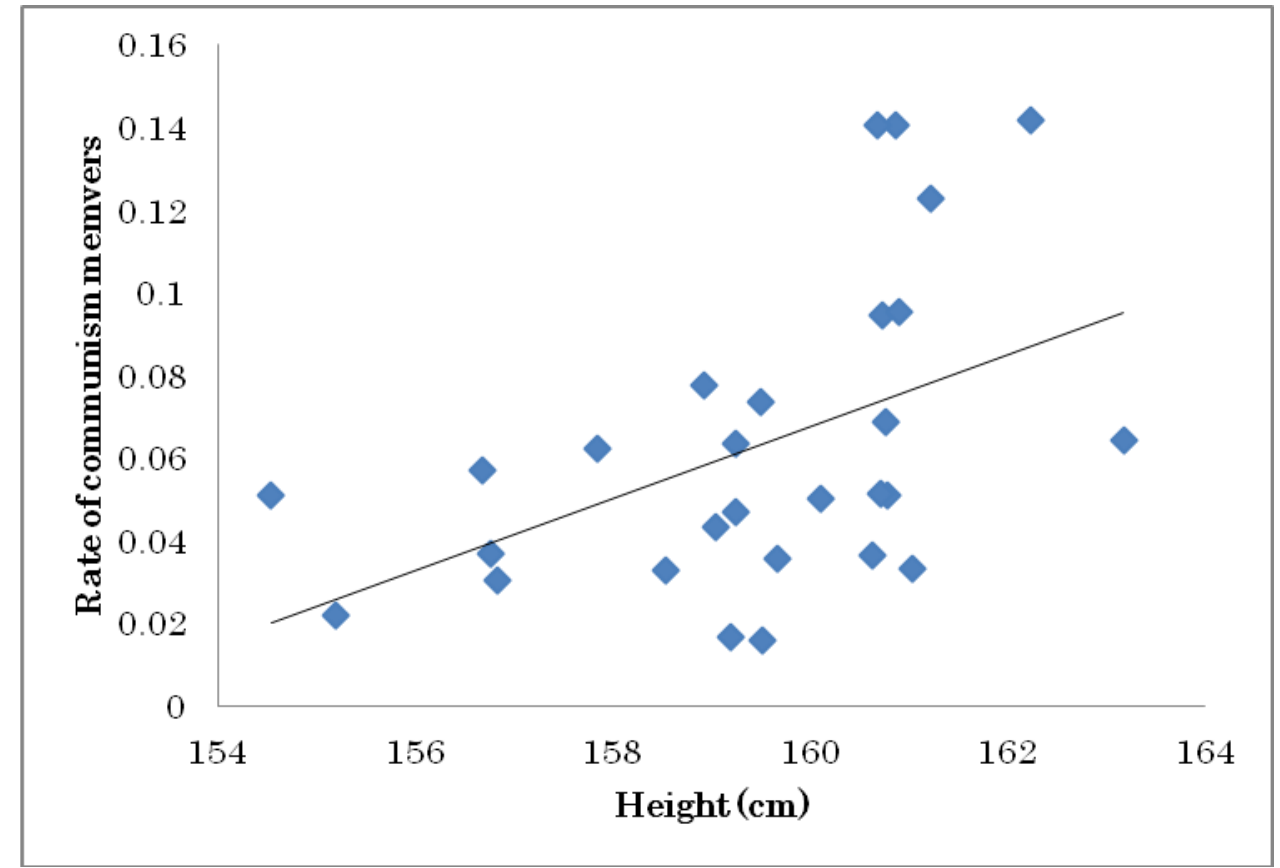

Figure 2(b). Association between height and Party membership for females. Note: mean value in each province is plotted. 
Table 1. Definition, and descriptive statistics, of variables used in empirical specifications.

\begin{tabular}{|c|c|c|c|c|c|}
\hline & Definitions & Mean & $\begin{array}{l}\text { Standard } \\
\text { deviation }\end{array}$ & $\operatorname{Max}$ & Min \\
\hline Income & Income level (thousand RMB) & 14.3 & 26.4 & 1,000 & 0 \\
\hline Party & 1 if respondent is member of the Communist Party, otherwise 0 . & 0.11 & $\cdots$ & 1 & 0 \\
\hline Height & Height $(\mathrm{cm})$ & 164 & 7.5 & 190 & 120 \\
\hline Father Party & $\begin{array}{l}1 \text { if respondent's father is member of the Communist Party, otherwise } \\
0 \text {. }\end{array}$ & 0.13 & $\cdots$ & 1 & 0 \\
\hline Mother Party & $\begin{array}{l}1 \text { if respondent's mother is member of the Communist Party, } \\
\text { otherwise } 0 .\end{array}$ & 0.02 & $\cdots-\cdot$ & 1 & 0 \\
\hline Age & Age at time of the survey & 43.2 & 14.0 & 98 & 18 \\
\hline Male & 1 if respondent is male, otherwise 0 . & 0.48 & $\cdots$ & 1 & 0 \\
\hline Schooling & Schooling years. & 0.51 & $\cdots--$ & 1 & 0 \\
\hline
\end{tabular}


Table 2. Mean difference test of income level between members of the Communist Party and others (thousand RMB).

\begin{tabular}{|c|c|c|c|c|}
\hline & $\begin{array}{l}\text { Member } \\
\text { (1) }\end{array}$ & $\begin{array}{l}\text { Non-member } \\
\text { (2) }\end{array}$ & $\begin{array}{l}\text { Difference in Income } \\
(1)-(2)\end{array}$ & t-values \\
\hline $\begin{array}{c}\text { Full sample } \\
\text { (I) }\end{array}$ & 22.8 & 13.1 & 9.8 & $8.74^{* * *}$ \\
\hline $\begin{array}{l}\text { Male sample } \\
\text { (II) }\end{array}$ & 24.1 & 16.2 & 7.9 & $4.49^{* * *}$ \\
\hline $\begin{array}{c}\text { Female sample } \\
\text { (III) }\end{array}$ & 19.7 & 10.2 & 9.5 & $8.90^{* * * *}$ \\
\hline $\begin{array}{l}\text { Difference in Income } \\
\text { (II)-(III) }\end{array}$ & 4.3 & 5.9 & & \\
\hline $\begin{array}{l}\mathrm{t} \text {-values } \\
\text { (I) versus (III) }\end{array}$ & 1.31 & $8.17^{* * *}$ & & \\
\hline
\end{tabular}

Note: $* * *$ indicates significance at the $1 \%$ level. 
Table 3. Mean difference test of height between members of the Communist Party and others (cm).

\begin{tabular}{lcccc}
\hline & $\begin{array}{c}\text { Member } \\
(1)\end{array}$ & $\begin{array}{c}\text { Non-member } \\
(2)\end{array}$ & $\begin{array}{c}\text { Difference in height } \\
(1)-(2)\end{array}$ & t-values \\
\hline Full sample & 168.3 & 164.0 & 4.2 & $13.8^{* * *}$ \\
Male sample & 170.9 & 169.7 & 1.2 & $4.21^{* * *}$ \\
Female sample & 161.1 & 159.4 & 1.7 & $4.37^{* * *}$ \\
\end{tabular}

Note: $* * *$ indicates significance at the $1 \%$ level. 
Table 4. Results for the full sample.

\begin{tabular}{|c|c|c|}
\hline & $\begin{array}{l}\text { (1) } \\
\text { Dependent variable: } \\
\text { Party }\end{array}$ & $\begin{array}{l}\text { (2) } \\
\text { Dependent variable: } \\
\text { Income }\end{array}$ \\
\hline & $\begin{array}{l}\text { Model: } \\
\text { Probit estimation }\end{array}$ & $\begin{array}{l}\text { Model: } \\
\text { Tobit estimation }\end{array}$ \\
\hline Party & & $\begin{array}{l}0.222^{* * *} \\
(2.68)\end{array}$ \\
\hline Height & $\begin{array}{l}0.003^{* * *} \\
(3.72)\end{array}$ & $\begin{array}{l}0.016^{* * *} \\
(2.89)\end{array}$ \\
\hline Father Party & $\begin{array}{l}0.058^{* * *} \\
(4.68)\end{array}$ & $\begin{array}{l}-0.005 \\
(-0.07)\end{array}$ \\
\hline Mother Party & $\begin{array}{l}0.092^{* * *} \\
(3.58)\end{array}$ & $\begin{array}{l}-0.066 \\
(-0.43)\end{array}$ \\
\hline Schooling & $\begin{array}{l}0.020^{* * * *} \\
(13.6)\end{array}$ & $\begin{array}{l}0.082^{* * *} \\
(8.15)\end{array}$ \\
\hline Age & $\begin{array}{l}0.007^{* * *} \\
(2.89)\end{array}$ & $\begin{array}{l}0.009 \\
(0.60)\end{array}$ \\
\hline Age squared & $\begin{array}{r}-0.0006 \\
(-0.24)\end{array}$ & $\begin{array}{l}0.0001 \\
(0.05)\end{array}$ \\
\hline Male & $\begin{array}{l}0.033^{* * *} \\
(2.62)\end{array}$ & $\begin{array}{l}0.147^{*} \\
(1.80)\end{array}$ \\
\hline Log-pseudo likelihood & -1249 & $-40,494$ \\
\hline $\begin{array}{l}\text { Left-censored } \\
\text { observations }\end{array}$ & & 118 \\
\hline $\begin{array}{l}\text { Endogeneity test for } \\
\text { Party } \\
\text { (Wu-Hausman F test) }\end{array}$ & & $\begin{array}{l}0.12 \\
p^{-} \text {value }=0.72\end{array}$ \\
\hline Observations & 4033 & 3581 \\
\hline
\end{tabular}

Notes: Numbers in parentheses are z-values. * $* *$ and *** indicate significance at the $10 \% 5 \%$ and $1 \%$ levels, respectively. Values not in parentheses are marginal effect for probit estimation and an estimate of the semi-elasticity $(d(\ln y) / d(x))$ for Tobit estimation. The following variables are also included but the results are not reported: residential province dummies, health status dummies, dummies for location of school respondents where graduated, dummies for number of family members, occupation dummies, dummies for ownership form of employer, marital status dummies and constant. Results for endogeneity test are obtained when 2SLS estimation is conducted on the condition that exogenous instrumental variables are Father Party and Mother Party. 
Table 5.Results for the male sample.

\begin{tabular}{lll}
\hline & $\begin{array}{c}(1) \\
\text { Dependent variable: } \\
\text { Party }\end{array}$ & $\begin{array}{l}(2) \\
\text { Dependent variable: } \\
\text { Income }\end{array}$ \\
& $\begin{array}{l}\text { Model: } \\
\text { Probit estimation }\end{array}$ & $\begin{array}{l}\text { Model: } \\
\text { Tobit estimation }\end{array}$ \\
& & $0.232^{* *}$ \\
& & $(2.13)$ \\
Party & $0.005^{* * *}$ & $0.019^{* *}$ \\
Height & $(3.07)$ & $(2.46)$ \\
Father Party & $0.100^{* * *}$ & 0.007 \\
& $(4.44)$ & $(0.07)$ \\
Mother Party & $0.073^{*}$ & -0.183 \\
& $(1.67)$ & $(-0.83)$ \\
Schooling & $0.029^{* * *}$ & $0.082^{* * *}$ \\
Age & $(10.7)$ & $(5.72)$ \\
Age squared & $0.012^{* *}$ & 0.021 \\
& $(2.55)$ & $(0.96)$ \\
\hline Log-pseudolikelihood & -0.00003 & -0.0001 \\
& $(-0.49)$ & $(-0.71)$ \\
Left-censored & -810 & $-23,204$ \\
observations & & \\
Endogeneity test for & & 30 \\
Party & & \\
(Wu-Hausman F test) & & 0.07 \\
Observations & 2136 & p-value=0.78 \\
& & 1979 \\
\hline
\end{tabular}

Notes: See Table 4 
Table 6.Results for the female sample.

\begin{tabular}{lll}
\hline & $\begin{array}{l}(1) \\
\text { Dependent variable: } \\
\text { Party }\end{array}$ & $\begin{array}{l}(2) \\
\text { Dependent variable: } \\
\text { Income }\end{array}$ \\
& $\begin{array}{l}\text { Model: } \\
\text { Probit estimation }\end{array}$ & $\begin{array}{l}\text { Model: } \\
\text { Topbit estimation }\end{array}$ \\
& & $0.193^{* *}$ \\
& & $(2.33)$ \\
Party & $0.002^{*}$ & $0.008^{*}$ \\
Height & $(1.83)$ & $(1.68)$ \\
& $0.026^{* *}$ & -0.045 \\
Father Party & $(2.25)$ & $(-0.71)$ \\
& $0.115^{* * *}$ & 0.212 \\
Mother Party & $(3.85)$ & $(1.61)$ \\
& $0.012^{* * *}$ & $0.072^{* * *}$ \\
Schooling & $(7.85)$ & $(8.18)$ \\
Age & 0.004 & $-0.023^{*}$ \\
Age squared & $(1.60)$ & $(-1.79)$ \\
& -0.00001 & $0.003^{* *}$ \\
\hline Log-pseudolikelihood & $(-0.03)$ & $(2.55)$ \\
Left-censored & -401 & $-16,554$ \\
observations & & \\
Endogeneity test for & & 88 \\
Party & & \\
(Wu-Hausman F test $)$ & & 1.36 \\
Observations & 1837 & $\mathrm{p}-\mathrm{value}=0.24$ \\
& & 1602 \\
\hline
\end{tabular}

Notes: See Table 4. 
Table 7. Parent's membership effect through political channel on income.

\begin{tabular}{lccc}
\hline & All & Male & Female \\
\hline Political channel & & $2.34 \%$ & $0.51 \%$ \\
Father membership & $1.29 \%$ & $1.69 \%$ & $2.22 \%$ \\
Mother membership & $2.04 \%$ & & No \\
Market channel & No & No & No \\
Mother membership & No & No & \\
\hline
\end{tabular}

Note: Membership effect is calculated based on results of Tables 4-6 as follows: (A) effect of father's (mother's) membership on probability that the respondent is a Communist Party member. (B) Effect of being a Communist Party member on income. Then, (A) multiplied by (B) indicates effect of father's (mother's) membership on income. 
Table 8. Channel of height's effect on income.

\begin{tabular}{llcl}
\hline & All & Male & Female \\
\hline $\begin{array}{l}\text { Effect of additional 1 cm } \\
\text { on income }\end{array}$ & & $0.82 \%$ \\
Market channel & $1.56 \%$ & $1.84 \%$ & $0.03 \%$ \\
Political channel & $0.07 \%$ & $0.11 \%$ & \\
\hline
\end{tabular}

Note: The political channel is calculated based on the results of Tables 4-6 as follows: (A) effect of $1 \mathrm{~cm}$ increase in height on the probability that the respondent is a Communist Party member. (B) Effect of being a Communist Party member on income. Then, (A) multiplied by (B) indicates the effect of height through the political channel. 